\title{
An Overview Study of Malaria Infection in Almaza Military Fever Hospital; An Egyptian Pilot Study
}

\author{
Runia Fouad El-Folly ${ }^{1}$, Amr Mohamed El-Sayed ${ }^{2}$, Mohamed Ezz Elarab ${ }^{3}$ \\ ${ }^{1}$ Department of Tropical Medicine, Faculty of Medicine, Ain Shams University, Cairo, Egypt. \\ ${ }^{2}$ Department of Infection, Military Medical Academy, Cairo, Egypt \\ ${ }^{3}$ Department of Hepatology and Gastroenterology, Internal Medicine Department, \\ Ahmed Maher Educational Hospital, Cairo, Egypt.
}

Corresponding Author Runia Fouad El-Folly

\section{E mail:} runiaelfollytm@yahoo. com

Key words: Complete blood picture: $C B C$; Plasmodium Falciparum: $P$. falciparum
Background and study aim: Malaria is a life-threatening disease caused by parasites that are transmitted to people through the bites of infected female Anopheles mosquitoes. The aim of this study is to study the clinical presentations and outcomes of malarial infected cases attending Almaza Military Fever Hospital in Cairo.

Patients and Methods: Fifty patients with malarial infection were selected from those admitted to Almaza Military Fever Hospital. The following investigations were done for all cases; (CBC), liver and renal function tests, serological tests (rapid diagnostic test for serum malarial antigens \& microscopic examination of peripheral blood film) and abdominal US.

Results: The majority of cases $(76 \%)$ was already diagnosed and was coming from

\section{INTRODUCTION}

Malaria is a life-threatening disease caused by parasites that are transmitted to people through the bites of infected female Anopheles mosquitoes. In 2015, 91 countries and areas had ongoing malaria transmission [1].

Between 2000 and 2015, malaria incidence among populations at risk (the rate of new cases) fell by $37 \%$ globally. In that same period, malaria death rates among populations at risk fell by $60 \%$ globally among all age groups, and by $65 \%$ among children under 5 years [2].

In 2015, approximately 3.2 billion people nearly half of the world's population were at risk of malaria. It was estimated that the number of malaria cases had decreased to 214 million (range: 149-303 million), and the number of deaths to 438000
Peace Keeping Mission Forces in Africa. Congo was the most malaria-infected place $(36 \%)$, then Ivory Coast (26\%). Most of cases $(80 \%)$ had intermittent fever. Six patients $(12 \%)$ were admitted at ICU. The thick film method was the most sensitive diagnostic test (98\%). $P$. falciparum was the commonest species among cases $(80 \%)$ then $P$. ovale $(20 \%)$. The best response in studied cases was poly-therapy $(84 \%)$ while mono-therapy was effective in only 5 patients $(10 \%)$, (82\%) of cases were cured, one patient died and one patient had a relapse while 2 patient (4\%) had recurred.

Conclusion: Thick film is the most sensitive and informative test among diagnostic test modalities. Combined therapy (polytherapy) is preferable than monotherapy.

(range: 236 000-635 000). Most malaria cases and deaths occur in sub-Saharan Africa. However, Asia, Latin America, and, to a lesser extent, the Middle East, are also at risk [2]. In 2015, 97 countries and territories had ongoing malaria transmission. Young children, pregnant women and non-immune travelers from malaria-free areas are particularly vulnerable to the disease when they become infected [2].

Malaria is preventable and curable, and increased efforts are dramatically reducing the malaria burden in many places. Sub-Saharan Africa carries a disproportionately high share of the global malaria burden. In 2015, the region was home to $88 \%$ of malaria cases and $90 \%$ of malaria deaths [1].

Malaria occurs mostly in poor tropical and subtropical areas of the world. In 
many of the countries affected by malaria, it is a leading cause of illness and death. In areas with high transmission, the most vulnerable groups are young children, who have not developed immunity to malaria yet, and pregnant women, whose immunity has been decreased by pregnancy [3]. The costs of malaria to individuals, families, communities, nations are enormous [3].

\section{PATIENTS AND METHODS}

This cross-sectional prospective study was held in co-operation between Tropical Medicine Department and Almaza Military Fever Hospital in the period from June 2015 to June 2016. Sample size was calculated to include 50 patients with malarial infection at $95 \%$ confidence interval and a power of 0.80 and an expected effect size of $50 \%$.

\section{Inclusion Criteria:}

Clinical manifestations (mainly fever with or without chills, sweating, headaches, nausea, vomiting, body aches or general malaise; signs; elevated temperatures, increased respiratory rate, weakness, mild jaundice, enlargement of the liver andlor spleen) [3]. As well, positive rapid malaria test.

The objectives of the study were explained to all patients who met the eligibility criteria and they were asked to sign a written consent form. Approval of the local ethical committee of the hospital was also obtained.

All the studied cases were subjected to the following:

Complete history taking and thorough clinical evaluation

Laboratory investigations: Including complete blood count (CBC), liver function tests (ALT, AST), renal function tests (serum creatinine, urea).

Serological tests: Rapid diagnostic test for serum malarial antigens, and microscopic examination of peripheral blood film stained with Giemsa stain.

Abdominal ultrasonography : This was done for all cases.

Therapy and Follow up: All patients after diagnosis were treated either by single drug regimen (Alexaquine or Mefloquine) the recommended dose $(25 \mathrm{mg} / \mathrm{kg})$ is dividing into two parts given at an arrival of 6-24 $\mathrm{h}$ then
Primaquine for 14 days [4] or by combined drug therapy in case of $P$. falciparum (Artesunate 2.4 $\mathrm{mg} / \mathrm{kg}$ given intravenously at 0,12 , and 24 hours, and then single daily dose for 2 days + Pyrimethamine \& Sulphadoxine three tablets once only) [5,6]. Treatment for other manifestation of malaria was done. The patients were followed up by another blood film after 2-3 days to show the parasitaemia and assess the response of the treatment regimen. If parasitaemia was persistent, the patient was shifted to other regimen.

Clinical outcome of the studied cases: Patients were discharged from hospital when they had been showed clinical improvement, mainly in the fever, and other manifestation. If any of the previous manifestations was present, we followed-up them after 15 and 30 days from discharge by clinical picture or laboratory investigations.

\section{Study methods:}

Serum samples: Ten milliliters venous blood was collected from each patient by clean vein puncture using disposable plastic syringes. Two $\mathrm{ml}$ of blood were delivered into plastic tube containing EDTA for performing Rapid diagnostic test.

\section{Malaria P.F/Pan Rapid Test Device (Whole Blood):}

It is a rapid, reliable and simple chromatographic immunoassay for the qualitative detection of circulating $P$. falciparum HRP-II antigen (histidine-rich protein II) and/or Pan-malarial Aldolase antigens found in Plasmodium falciparum, Plasmodium vivax, Plasmodium ovale and Plasmodium malariae in whole blood (Figure 1).

\section{Procedure:}

The device was labeled with patient name or identification number, then the specimen was transferred by a pipette $10 \mathrm{ul}$ of whole blood to well-1 (W1) of the test device, then 3 full drops of buffer was added to well-2 (W2), and the timer was started. We avoided trapping air bubbles in W1. At the end of 5 minutes, we added 1 full drop of buffer to W1, waiting for the colored line(s) to appear. The result was read at 15 minutes (not after 20 minutes).

\section{Interpretation of results:}

- Positive: Two or Three distinct colored lines appeared. P. falciparum or mixed malaria 
infection: one line appeared in the control region, one line appeared in P.f line region. $P$. falciparum infection: one line appeared in the control region, and one line appeared in P.f line region. Non-P. falciparum species infection: one line appeared in the control region, and one line appeared in Pan line region.

- Negative: Only one colored line appeared in the control region.

- Invalid: Control line failed to appear. Insufficient specimen volume or incorrect procedural techniques were the most likely reasons for control line failure. The procedure was revised and the test was repeated with a new test device.

Thin \& Thick blood films: Thin blood films were prepared by placing the edge of the spreader slide in a drop of blood and smearing the blood along the surface. Films were allowed to air-dry and were fixed with absolute methanol. For thick blood films, a blood spot was stirred in a circular motion with the corner of the slide and slides were left to dry without fixation. After drying of blood films, they were stained with diluted Giemsa $(1: 20$, vol/vol) for 20 minutes and washed in buffered water. To ensure good quality of staining and standardization of blood film examination and reporting, the amount of blood used to make blood films, especially thick films, was kept as constant as possible and the blood was spread evenly over a specified area of the slide $(15 \times 15 \mathrm{~mm}$ for thick films $)$. Each slide was subjected to preliminary screening using low power objectives $(\times 10$ and $\times 40)$ followed by examination of at least 100 microscopic fields using high power objectives $(\times 100)$. Slides were examined by 2 microscopic experts and suspicious slides were examined by a third expert (Figure 2) [7].

\section{Statistical Analysis:}

The collected data were coded, tabulated, and statistically analyzed using SPSS program (10.0) (Statistical Package for Social Sciences) for Windows XP. Descriptive statistics were done for numerical parametric data as mean, standard deviation (mean $\pm \mathrm{SD}$ ) and minimum \& maximum of the range, while they were done for categorical data as number and percentage. Description of qualitative variables was done by frequency and percentage. The diagnostic cut off and the related sensitivity and specificity were determined.

\section{RESULTS}

The current study showed that the majority of patients $(\mathrm{No}=42(84 \%))$ were $(20-40)$ years old and 46 of them (92\%) were military staff. According to the bases of selection of the studied patient, most of them $(\mathrm{No}=38(76 \%))$ were diagnosed as imported malaria coming from Peace Keeping Mission Forces in Africa, while (24\%) were presenting with prolonged fever (710 days) for investigation. The previous $24 \%$ of the studied patients was further classified into; eight patients $(16 \%)$ were diagnosed as relapsing malaria and four patients $(8 \%)$ were diagnosed as endemic acquired malaria.

N.B: Imported Malaria: Malaria acquired outside a specific geographic area (Egypt). Relapsing malaria: occur after primary attack due to reactivation of hypozoites of parasite in liver up to 3-5 years after primary infection. Endemic Acquired malaria: Malaria acquired at malariaendemic countries.

The geographical distribution of malaria parasite showed that Congo was the most malariainfected place $(36 \%)$, and Ivory Coast was coming next in frequency (26\%) (Figure 3).

Concerning the clinical presentations, all patients $(100 \%)$ had a fever as presenting symptoms, associated with rigors \& sweating. Three patients (6\%) were comatosed, two patients (4\%) had convulsion with neck stiffness, five patients $(10 \%)$ with dark urine had high grade fever and six patients (12\%) was admitted at ICU (Table 1). It also, revealed the outcome of the six patients $(12 \%)$ that was admitted at ICU, two patients were cured, two patients presenting with anemia, one patient presenting with renal impairment and one patient died.

As regards to the past history of the studied malarial-infect patients; ten patients $(20 \%)$ had taken doxycycline, 8 patients (16\%) had mefloquine as preventive antimalarial drugs and 32 patients (64\%) had no any preventive therapy. Twenty patients among all (40\%) had a past history of malaria infection,

The current study assessed the diagnostic tests. The thick film method was more sensitive (98\%) than thin film test (Table 2). P.falciparum was the commonest species among the studied cases $(\mathrm{No}=40(80 \%))$ and P.ovale coming next in frequency $(\mathrm{No}=10(20 \%))$. 
The laboratory investigations didn't reveal any significant findings while abdominal ultrasound only revealed that twenty eight patients $(56 \%)$ had hepatomegaly and twenty four (48\%) had splenomegaly.

Concerning the therapeutic responses of the studied patients, the best response was detected after poly-therapy $(\mathrm{No}=42(84 \%))$ while monotherapy was effective in only 5 patients only
(10\%) as had shown in (table 3). Also, it revealed the clinical outcome of the studied cases, forty-one patients ( $82 \%$ ) were cured, one patient $(2 \%)$ died and one patient $(2 \%)$ had a relapse while 2 patients (4\%) had recurred. Table (4) showed the comparative study between complicated \& non-complicated malaria:

Table (1) : Severe malarial manifestations \& Analysis of the patients that had admitted to ICU

\begin{tabular}{|c|c|c|c|c|c|c|c|c|c|c|c|c|c|c|}
\hline \multirow[b]{2}{*}{$\begin{array}{l}\text { Severe malarial } \\
\text { manifestations }\end{array}$} & \multicolumn{3}{|c|}{ Conscious level } & \multicolumn{3}{|c|}{ Neuro-psychiatric } & \multicolumn{2}{|c|}{ Renal } & \multicolumn{2}{|c|}{ Chest } & \multicolumn{3}{|c|}{ Other } & \multirow[b]{2}{*}{ 己ِ } \\
\hline & 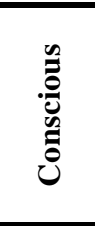 & 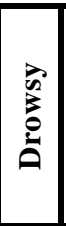 & 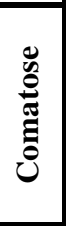 & 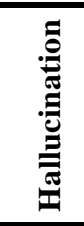 & 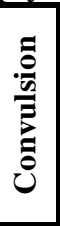 & 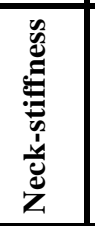 & & 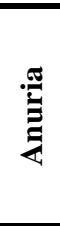 & ن & 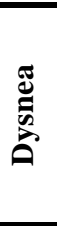 & 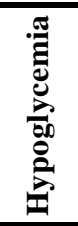 & 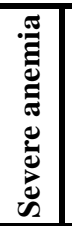 & 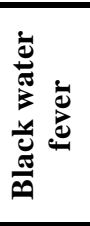 & \\
\hline Frequency & 38 & 9 & 3 & 12 & 2 & 2 & 3 & 1 & 9 & 9 & 12 & 7 & 5 & 6 \\
\hline Percent \% & 76 & 18 & 6 & 24 & 4 & 4 & 6 & 2 & 18 & 18 & 24 & 14 & 10 & 12 \\
\hline $\begin{array}{l}\text { Analysis of } 6 \text { cases } \\
\text { that had admitted } \\
\text { to ICU }\end{array}$ & \multicolumn{2}{|c|}{ Pt (1) } & \multicolumn{2}{|c|}{ Pt (2) } & \multicolumn{2}{|c|}{ Pt (3) } & \multicolumn{4}{|c|}{$\operatorname{Pt}(4)$} & \multicolumn{2}{|c|}{ Pt (5) } & \multicolumn{2}{|c|}{ Pt (6) } \\
\hline$\overline{\text { Age }}$ & \multicolumn{2}{|c|}{22} & \multicolumn{2}{|c|}{19} & \multicolumn{2}{|c|}{32} & \multicolumn{4}{|c|}{20} & \multicolumn{2}{|c|}{23} & \multicolumn{2}{|c|}{21} \\
\hline Manifestations & \multicolumn{6}{|c|}{$\begin{array}{l}\text { Cerebral malaria } \\
\text { - Coma. } \\
\text { - Hyperpyrexia } \\
\text { - Convulsion. } \\
\text { - Hallucination. } \\
\text { - Neck stiffness. } \\
\text { - Sever anemia. } \\
\text { - Thrombocytopenia. } \\
\text { - Hypoglycemia. } \\
\text { - Black water fever. }\end{array}$} & \multicolumn{8}{|c|}{$\begin{array}{l}\text { Sever malaria } \\
\text {-Drowsy. } \\
\text {-Hyperpyrexia. } \\
\text {-Hallucination. } \\
\text { - Sever anemia. } \\
\text { - Thrombocytopenia. } \\
\text { - Hypoglycemia. } \\
\text { - Black water fever. } \\
\text { - Anuria. }\end{array}$} \\
\hline $\begin{array}{l}\text { Laboratory } \\
\text { Features }\end{array}$ & \multicolumn{14}{|c|}{$\begin{array}{l}\text { - Hypoglycemia }<50 \mathrm{mg} / \mathrm{dl} \text {. } \\
\text { - Metabolic acidosis. } \\
\text { - Severe anemia }<7 \mathrm{gm} / \mathrm{dl} \text {. } \\
\text { - Thrombocytopenia }<150 / \mathrm{ml} \\
\text { - Hemoglobinuria. } \\
\text { - Renal impairment. } \\
\text { - Hyperparasitamia. }\end{array}$} \\
\hline Malaria species & \multicolumn{14}{|c|}{ P. falciparum } \\
\hline Treatment & \multicolumn{14}{|c|}{$\begin{array}{l}\text { Coma: } \\
\text { - Maintain airway } \\
\text { - Ventilator support, cardiac monitoring. } \\
\text { - Exclude other treatable causes of coma (e.g. hypoglycemia, bacterial meningitis). } \\
\text { - Avoid harmful treatments. } \\
\text { Hyperpyrexia: } \\
\text { - Administer tepid sponging and antipyretic drugs. } \\
\text { - Paracetamol is preferred over more nephrotoxic drugs. } \\
\text { Correction of fluids, electrolytes and acid base balance. } \\
\text { Blood transfusion. } \\
\text { Artesunate is drug of choice } 2.4 \mathrm{mg} / \mathrm{kg} \text { iv at } 0 \mathrm{hr}, 12 \mathrm{hr} \text { and } 24 \mathrm{~h} \text { then daily for } 6 \text { days till pt can } \\
200 \text { mg daily by mouth for } 7 \text { days }[\mathbf{2 6}] \text {. }\end{array}$} \\
\hline Outcome & \multicolumn{4}{|c|}{ - Anemia } & \multicolumn{2}{|c|}{ Death } & \multirow{2}{*}{\multicolumn{4}{|c|}{ R. impairment }} & \multicolumn{4}{|c|}{ Cured } \\
\hline Frequency & \multicolumn{4}{|c|}{$-2(4 \%)$} & \multicolumn{2}{|c|}{$1(2 \%)$} & & & & & \multicolumn{4}{|c|}{$2(4 \%)$} \\
\hline
\end{tabular}

\# Descriptive Data 
Table (2) : Diagnostic characteristics of Thick and Thin blood film in diagnosis of Malaria

\begin{tabular}{|l|c|c|}
\hline \multicolumn{1}{|c|}{ Character Thick blood film } & Value & (95\% CI) \\
\hline Sensitivity \% & 98 & $93.7-98.0$ \\
\hline Specificity \% & 100 & $100.0-100.0$ \\
\hline Positive Predictive value (PPV) \% & 100 & $100.0-100.0$ \\
\hline Negative Predictive value (NPV) \% & 98.5 & $93.2-98.5$ \\
\hline Diagnostic accuracy (DA) \% & 100 & $100.0-100.0$ \\
\hline \multicolumn{2}{|c|}{ Thin blood film } \\
\hline Sensitivity \% & 84 & $79.7-84.0$ \\
\hline Specificity \% & 100 & $100.0-100.0$ \\
\hline positive Predictive value (PPV) \% & 100 & $100.0-100.0$ \\
\hline Negative Predictive value (NPV) \% & 93 & $95.8-93.0$ \\
\hline Diagnostic accuracy (DA) \% & 100 & $100.0-100.0$ \\
\hline
\end{tabular}

\# Descriptive Data N.B: Total=50, CI: Confidence interval

Table (3) : Therapeutic responses \& Clinical outcome of the studied patients

\begin{tabular}{|c|c|c|c|c|c|c|c|c|}
\hline $\begin{array}{c}\text { Therapeutic } \\
\text { responses }\end{array}$ & \multicolumn{2}{|c|}{$\begin{array}{l}\text { Response to single } \\
\text { (ttt) of Alexaquine } \\
\text { or mefloquine }\end{array}$} & \multicolumn{3}{|c|}{$\begin{array}{c}\text { Response to } \\
\text { combined(ttt) } \\
\text { (Artesunate+ } \\
\text { pyrimethamine+ } \\
\text { Sulphadoxine) } \\
\end{array}$} & \multicolumn{2}{|c|}{$\begin{array}{c}\text { Resistance to } \\
\text { single } \\
\text { responsive to } \\
\text { combined } \\
\text { (ttt) } \\
\end{array}$} & Total \\
\hline Frequency & \multicolumn{2}{|c|}{5} & \multicolumn{3}{|c|}{42} & \multicolumn{2}{|r|}{3} & 50 \\
\hline Percent \% & \multicolumn{2}{|c|}{10} & \multicolumn{3}{|c|}{84} & \multicolumn{2}{|r|}{6} & 100 \\
\hline \multirow[b]{2}{*}{$\begin{array}{l}\text { Clinical } \\
\text { outcome }\end{array}$} & \multirow[b]{2}{*}{ Cured } & \multicolumn{2}{|c|}{ Recurrence } & \multicolumn{3}{|c|}{ Complications } & \multirow[b]{2}{*}{ Death } & \multirow[b]{2}{*}{ Total } \\
\hline & & 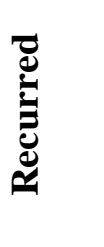 & $\frac{\mathscr{U}}{\frac{\pi}{0}}$ & & 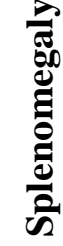 & 馬 & & \\
\hline Frequency & 41 & 2 & 1 & 2 & 2 & 1 & 1 & 50 \\
\hline Percent \% & 82 & 4 & 2 & 4 & 4 & 2 & 2 & 100 \\
\hline
\end{tabular}

\# Descriptive Data

N.B: @ Recurred Malaria; is a new malaria infection after new mosquito bite. @ Relapsed Malaria occurs after primary attack due to reactivation of hypozoites of parasite in liver up to 3-5 years after primary infection. 
Table (4) : Comparative study between complicated \& non-complicated malarial-infected patients

\begin{tabular}{|c|c|c|}
\hline Variables $(\mathrm{No}=\mathbf{5 0})$ & $\begin{array}{c}\text { Non-complicated Malaria } \\
(n=44)\end{array}$ & Complicated Malaria $(n=6)$ \\
\hline Age & $19-43$ yrs & $19-34$ yrs \\
\hline Symptoms & $\begin{array}{c}\text { Intermittent or Remittent fever. } \\
\text { Conscious. } \\
\text { Dark urine. } \\
\text { Vomiting. } \\
\end{array}$ & $\begin{array}{c}\text { Continuous high grade fever. } \\
\text { Comatose or drowsy. } \\
\text { Black water fever. }\end{array}$ \\
\hline Signs & $\begin{array}{l}\text { Mild to moderate anemia } \\
\text { Hypoglycemia. } \\
\text { Enlarged liver, spleen or both }\end{array}$ & $\begin{array}{c}\text { Severe anemia. } \\
\text { Hypoglycemia } \\
\text { Hepatoslenomegaly. }\end{array}$ \\
\hline Past history & Malaria infection & No malaria infection \\
\hline Chemoprophylaxis & $\begin{array}{l}\text { Yes or incomplete course or no } \\
\text { Chemoprophylaxis }\end{array}$ & $\begin{array}{l}\text { Incomplete course or no } \\
\text { Chemoprophylaxis }\end{array}$ \\
\hline Laboratory Investigations & $\begin{array}{l}\text { Hb } 7-15 \mathrm{gm} / \mathrm{dl} \\
\text { Platelets } 50-450 / \mathrm{ml} \\
\text { Bilirubin } 0.5-1.0 \\
\text { ALT } 25-75 \\
\text { AST } 20-70 \\
\text { Creat } 0.7-1.4\end{array}$ & $\begin{array}{l}\text { Hb }<7 \mathrm{gm} / \mathrm{dl} \\
\text { Platelets }<50 / \mathrm{ml} \\
\text { Bilirubin }>1.0 \\
\text { ALT } 40-100 \\
\text { AST } 40-100 \\
\text { Creat }>1.4\end{array}$ \\
\hline $\mathbf{U} / \mathbf{S}$ & $\begin{array}{l}\text { Liver size } 13-15 \mathrm{~cm} \\
\text { Spleen size } 11-14 \mathrm{~cm}\end{array}$ & $\begin{array}{l}\text { Liver size }>15 \mathrm{~cm} \\
\text { Spleen size }>14 \mathrm{~cm}\end{array}$ \\
\hline ICU & No- admitted & Admitted \\
\hline Line of treatment & Mono therapy or Poly therapy & Poly therapy \\
\hline Outcomes & $\begin{array}{ll}\text { - } & 39 \text { Cured } \\
- & 2 \text { splenomegally } \\
- & 3 \text { Recurrence }\end{array}$ & $\begin{array}{ll}- & 2 \text { Cured } \\
- & 2 \text { Anemia } \\
- & 1 \text { Renal impairment } \\
- & 1 \text { Death }\end{array}$ \\
\hline
\end{tabular}

\# Descriptive Data

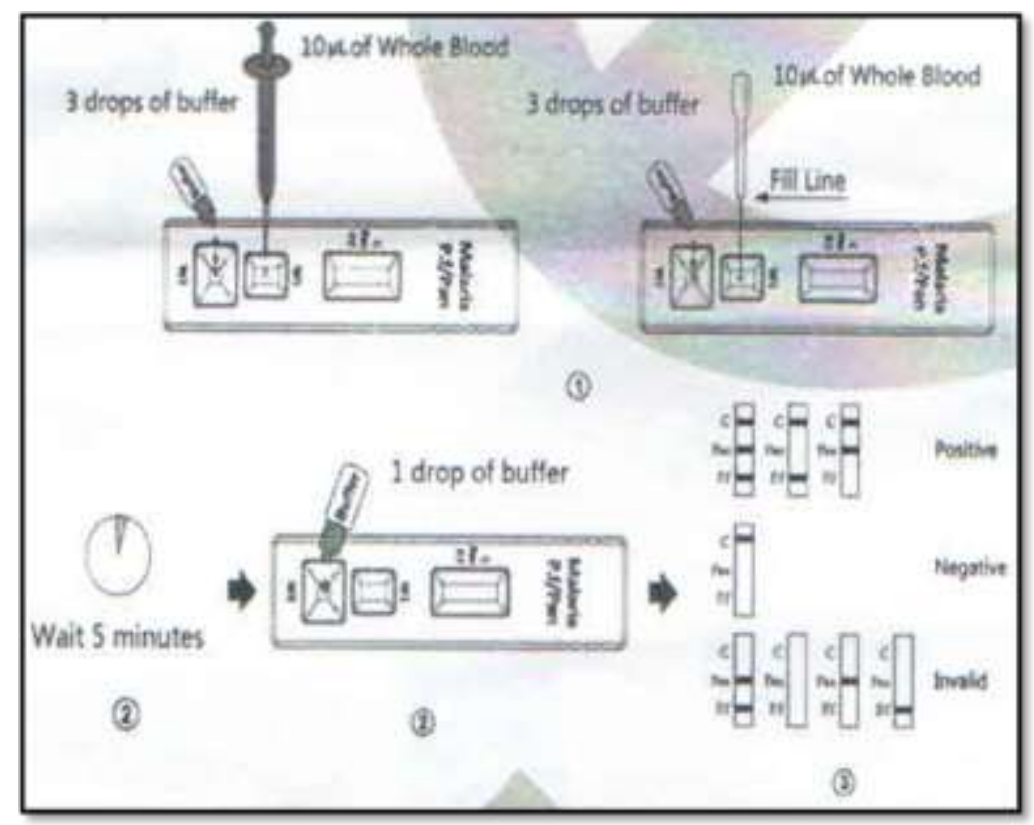

Figure (1): Diagram of rapid diagnostic test of whole blood malarial antigen

(Bio Tina@Gmbh,www.eu-biotina.com)। 


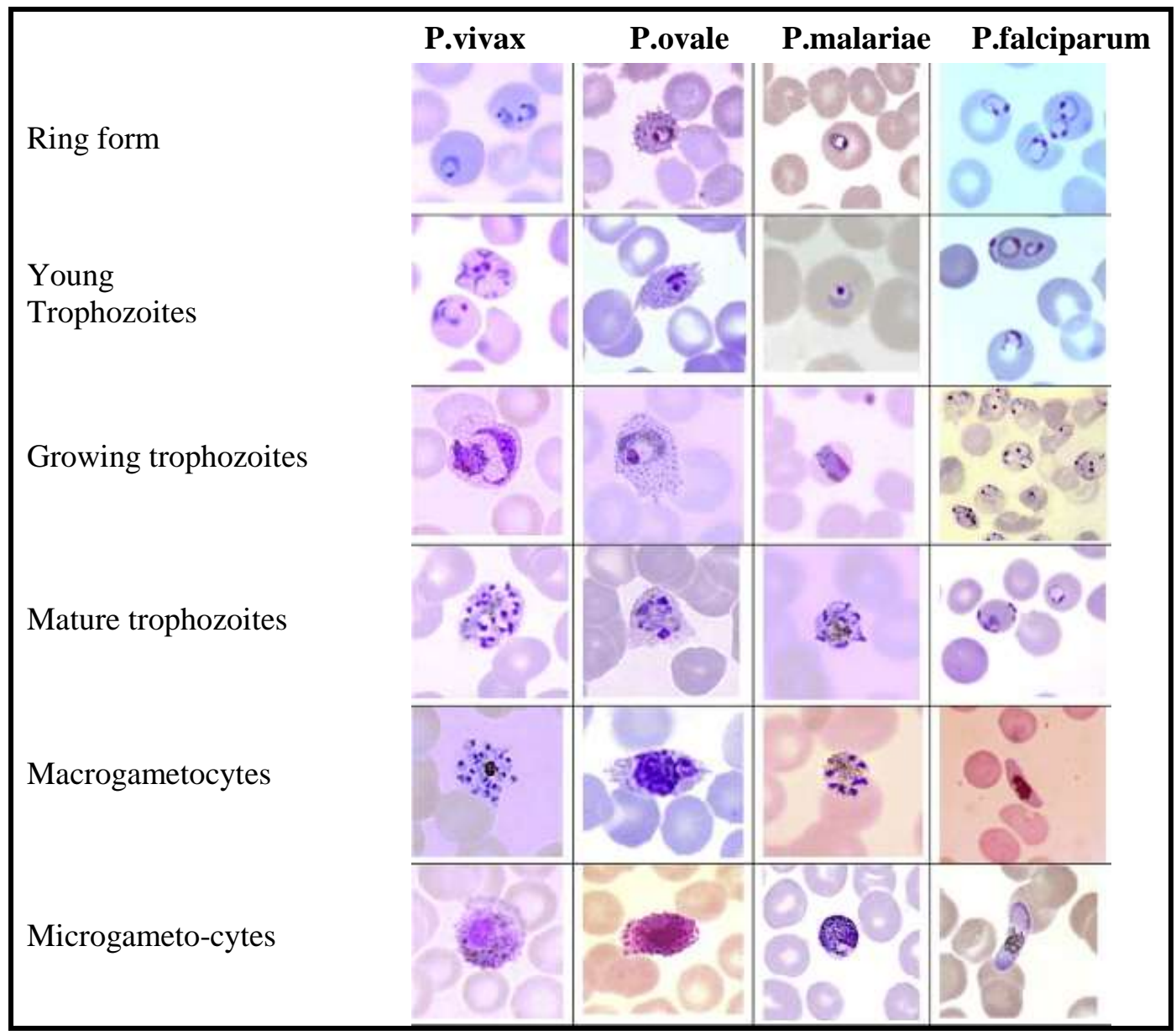

Figure (2): Blood stages of Plasmodium [7]

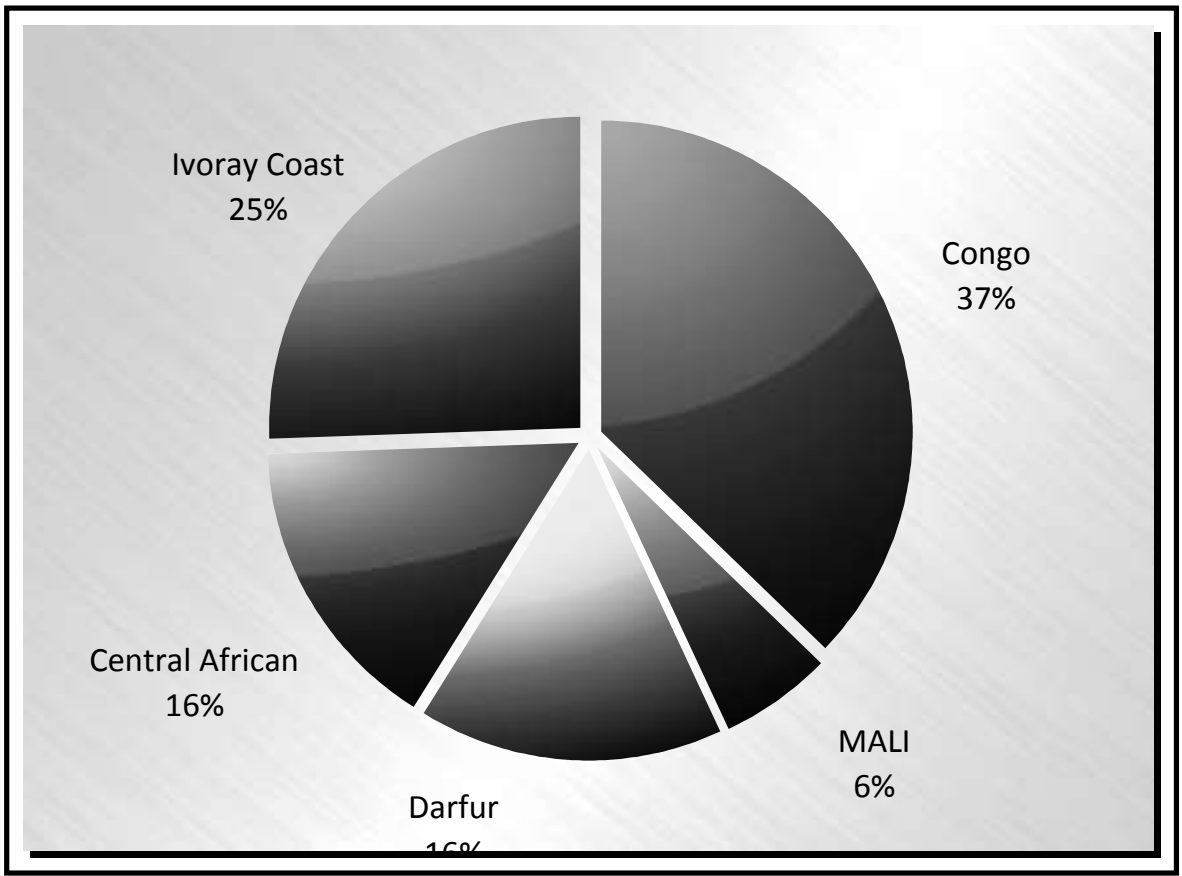

Figure (3): Geographical distribution of malaria parasite among studied cases (in Africa). 


\section{DISCUSSION}

Malaria remains one of the major killers of humans' population worldwide, threatening the lives of more than one third of the world's population [1]. In Egypt, Malaria is eradicated since 1998 until June 14, 2014. Between lates May to mid-June, 19 locally-acquired P. vivax malaria cases were identified in one village of the Aswan Governorate [8]. Few Egyptian studies had assessed the status of malaria infection in Egypt.

The study shows that the Egyptian malarial patients were recruited from malarial areas in Africa. Congo was the most malaria-infected place $(36 \%)$ and Ivory Coast coming next in frequency $(26 \%)$. The reasons are not clear, although it is thought renewed fighting by militia groups has made it increasingly difficult for people to access prevention and treatment [9].

Fever was the main presenting symptoms of malaria among all the studied patients $(100 \%)$. This is in consistent with Ella et al. [10] who explained that fever is a characteristic feature of P. falciparum infection. The symptoms of malaria include paroxysms defined by intense chills; fever and sweating caused as new merozoites burst from the erythrocyte and infect more cells [11]. In the current study the majority of patients experience fever, sweating and rigors (100\%), myalgia (86\%), headache $(76 \%)$. This is in consistent with $\mathrm{He}$ et al. [12] who explained that patients with no or incomplete chemoprophylaxis, like patients in the current study, had fever, sweating, rigors (96\%), headache $(74 \%)$ and myalgia (86\%) in those with malaria.

Five patients $(10 \%)$ had black water fever (black urine, fever, drowsiness, sweating and other symptoms suggestive of severe malaria). This is the clinical manifestation of This is comparable with study carried out by Bodi et al. [13] who explained that rainy season, low parasitaemia were the major risk factors significantly associated with haemoglobinuria, black water fever first described in non-immune European expatriates who lived in endemic malaria regions.

Six of the studied malarial patients $(12 \%)$ in the current study, was admitted at ICU. Three of them (6\%) were comatosed have "Glasgow Coma Scale" less than 4 as cerebral malaria and other three patients were drowsy have GCS less than 9 presenting with sever malaria manifestations. These patients had hyperpyrexia, convulsion, hallucination, neck stiffness, severe anemia $(<7 \mathrm{gm} / \mathrm{dl}$.), thrombocytopenia $(<50 / \mathrm{ml})$, hypoglycemia $(<50 \mathrm{mg} / \mathrm{dl})$ and black water fever, positive rapid diagnostic test and blood smear showed causative species was P. falciparum. This is in agreement with Cserti-Gazdewich et al. [14] who explained that $4.5 \%$ of his studied malarial patients were comatosed and severe anemia was observed in $65 \%$ of patients with severe malaria.

The current study reveals that ten patients (20\%) had taken doxycycline, eight patients $(16 \%)$ had taken mefloquine as chemoprophylaxis and thirty-two patients $(56 \%)$ had not received any previous preventive antimalarial drugs. Twenty patients (40\%) among those who received doxycycline and those who did not received any preventive therapy, had past history of previous malarial infection. Though mefloquine was used in $(16 \%)$ of cases, yet it had a better clinical outcome, that was proved previously by Schlangenhauf [15] and also documented in 2006 by federal ministry of health Sudan/WHO/ National malaria central program [16].

A congress of the WHO produced a document entitled new perspectives in Malaria Diagnosis (WHO/MAL/2000.1091) [17]. Certain recommendations were presented on nonmicroscopic rapid diagnostic tests (RDT). The document concluded that results from these test devices were accurate. Also, it was sensitive (98$100 \%$ ) in detecting of parasitaemia and its ability to distinguish viable parasites from parasite products such as antigens or nucleic acids not associated with viable organisms and also to indicate the prediction of treatment outcomes or resistance to common antimalarial drugs [18].

The present study showed that the thick blood film method was the most sensitive test (98\%) while the thin film was much easier in identifying Plasmodium species. This is in consistent with Rescigno and Borrow [19] who reported that the thick blood film concentrates the layers of red blood cells (RBC) on a small surface by a factor of 20 to 30 and is stained as an unfixed preparation using fields stain or diluted wrights or Giemsa stain. The thick blood film provides enhanced sensitivity of the blood film technique and is much better than the thin film for detecting the low levels of parasitaemia and reappearance of circulating parasites during infection recrudescence or relapse [19].

The thin blood film is often preferred for routine estimation of the parasitaemia because the 
organisms are easier to see and count. The ability to count parasites in sequential blood films enables the response to therapy to be monitored, particularly for P.falciparum infections [20].

The Plasmodium falciparum was the commonest species found among the studied cases (80\%) and P.ovale is coming next in frequency (20\%). These were explained that $P$. falciparum is found in tropical and subtropical areas, and especially in Africa where this species predominates [21].

Concerning the therapeutic responses of the studied cases, the best response in studied cases was detected with poly-therapy (84\%) such as Artesunate plus sulphadoxine plus pyrimethamine (Artecospe) while mono-therapy as Mefloquine was effective in 5 patients $(10 \%)$. This agrees with Luyendyk et al. [22] and documented in 2006 by Federal Ministry of Health Sudan WHO/National malaria central Programme [16]. It seems that the efficacy of variable lines of therapy is different according to variations in place and time [22].

Concerning the clinical outcomes of the studied cases, Most of the studied malarial-infected patients (82\%) were cured and discharged from hospital when they had been shown clinical improvement, mainly the fever; if present we followed them up after 15 and 30 days from discharge. Some patients (10\%) had been discharged from hospital with complications like anemia, renal impairment and splenomegaly for follow up, three patients $(6 \%)$ admitted again after 2-6 months with recurrence of malarial infection and one patient died. Because he did not received chemoprophylaxis during his trip to Africa, so he was infected with P. falciparum that was complicated by cerebral malaria, this is the same outcome that was described by Suh et al. [23] and Geerligs et al. [24]. Artesunate was the drug of choice for cerebral malaria $2.4 \mathrm{mg} / \mathrm{kg}$ iv at $0 \mathrm{hr}, 12 \mathrm{hr}$ and $24 \mathrm{~h}$ then daily till patient can take it orally, paracetamol is preferred over more nephrotoxic drugs for hyperpyrexia, blood transfusion for severe anemia and correction of fluids, electrolytes and acid base balance $[\mathbf{2 5 , 2 6 ]}$.

Concerning the comparative results between complicated \& non-complicated malarial cases in the present study, younger age patients with no past history of malaria infection or chemoprophylaxis were liable to complicated malaria.

Therefore, Malaria should be considered in the febrile patient even with a normal WBC who coming out of an endemic area, malarial-infected younger age people with no past history of malaria infection or chemoprophylaxis were liable to complicated malaria.

\section{CONCLUSION}

In Egypt, no endogenous malaria cases have been reported since1998 until 2014 a malaria outbreak was discovered in Aswan. Malaria cases in Egypt are usually coming from endemic area in Africa. Thick film is the most sensitive and informative test among all diagnostic test modalities. Mortality due to malaria disease is unusual, and may result from improper chemoprophylaxis and missed diagnosis or late treatment. Combined therapy (polytherapy) is preferable than monotherapy, as it is more effective among the studied malarial cases. Tools of prophylaxis are insect repellents, protective clothes, bed nets and chemoprophylaxis.

\section{Acknowledgements:}

To Military Medical Academy, Almaza Fever Hospital, non-profit organizations that support us with malaria's cases. They had no role in gathering, analyzing or interpreting the data.

This research did not receive any specific grant from funding agencies in the public, commercial, or not-for-profit sectors.

\section{REFERENCES}

1- World Health Organization. Media Centre > Malaria > Fact sheet, Updated April 2016. Available at http: //www.who.int / mediacentre / factsheets / fs094/en/

2- World Malaria Report. Available: http://www. who. int/malaria/publications/world-malariareport-2015/report/en/

3- Centers for Disease Control and Prevention. CDC $<$ Malaria < Malaria Worldwide. Available: http://www.cdc.gov/Malaria/Malaria_worldwide/ inde x.html, 2015.

4- Price R, Simpson JA, Teja-Isavatharm P, Than MM, Luxemburger C, Heppner DG., et al. Pharmacokinetics of mefloquine combined with artesunate in children with acute falciparum malaria. Antimicrob Agent and Chemoth 1999; 43: 341-346.

5- McIntosh HM, Olliaro P. Artemisinin derivatives for treating sever malaria. Cochrane Database Syst Rev 2000; 2: CD000527.

6- Newton PN, Angus BJ, Chierakul W, Dondorp A, Ruangveerayuth R, Silamut K, et al. (ArtemetherQuinine Meta-analysis Study Group). A meta- 
analysis using individual patient data of trials comparing artemether with quinine in the treatment of severe falciparum malaria. Trans $R$ Trop Med Hyg 2001; 95: 637-650.

7- Chotivanich K, Silamut K, Day NPJ. Laboratory diagnosis of malaria infection-a short review of methods. Aust J Med Sci 2006; 27(1): 11-15.

8- Kandeel A, Haggag AA, Abo El Fetouh M, Naiel M, Refaey SA, Hassan AH, et al. Control of malaria outbreak due to Plasmodium vivax in Aswan Governorate, Egypt. East Medit Health J 2016; 22(4): 274-279.

9- Iaccino L. World Malaria Day 2014: Top Five Countries Most Affected by Malaria. Available at http://www.ibtimes.co.uk / world - malaria - day 2014 -top-five-countries-most - affected - bymalaria- 1445969, 2014.

10- Dzeing-Ella A, Obiang PCN, Tchoua R, Planche T, Mboza B, Mbounja $M$, et al. Severe falciparum malaria in Gabonese children: clinical and laboratory features. Malar J. 2005; 4: 1.

11- Kappe SH, Vaughan AM, Boddey JA, Cowman AF. That was then but this is now: malaria research in the time of an eradication agenda. $S c i$ 2010; 328: 862-866.

12- He D, Zhang Y, Liu X, Guo S, Zhao D, Zhu Y. Epidemiological and Clinical Features of Plasmodium falciparum Malaria in United Nations Personnel in Western Bahr el Ghazal State, South Sudan. 2013, https://doi.org/10.1371/journal.pone.0055220

13- Bodi JM, Nsibu CN, Longenge RL, Aloni MN, Akilimali PZ, Tshibassu PM. Blackwater fever in Congolese children: a report of clinical, laboratory features and risk factors. Malar J 2013; 12: 205, https://doi.org/10.1186/14752875-12-205.

14- Cserti-Gazdewich CM, Dhabangi A, Musoke C, Ssewanyana I, Ddungu H, NakibonekaSsenabulya D., et al. Inter-relationships of cardinal features and outcomes of symptomatic pediatric Plasmodium falciparum MALARIA in 1,933 children in Kampala, Uganda. Am J Trop Med Hyg 2013; 88: 747-756.

15- Schlagenhauf P. Standby emergency treatment of malaria in travelers. In: Schlagenhauf P, editor. Travelers' malaria. Hamilton, Ontario: BC Decker Inc. 2001; 446-462.
16- Federal Ministry of Health - National Malaria Control Programme . National Malaria Strategic Plan 2007-2012. Khartoum; 2006.

17- World Health Organization. Malaria diagnosisnew perspectives.Report of a joint WHO/USAID informal consultation, October 25-27, 1999. WHO/MAL/2000. 1091. World Health Organization, Geneva, Switzerland. 1999.

18- Srinavasan S, Moody AH, Chiodini PL. Comparison of blood-film microscopy, the OptiMAL ${ }^{\circledR}$ dipstick, Rhodamine 123 and PCR for monitoring anti-malarial treatment. Ann Trop Med Parasitol 2000;94:227-232. http://dx.doi. org/ 10.1080/00034980050006393.

19- Rescigno M, Borrow P. The host-pathogen interaction: New themes from dendritic cell biology. Cell 2001; 106: 267-270.

20- Tascon RE, Soares CS, Ragno S, Stavropoulos E, Hirst EM, Colston MJ. Mycobacterium tuberculosis-activated dendritic cells induce protective immunity in mice. Immunology 2000; 99: 473-480.

21- Centers for Disease Control and Prevention. CDC > DPDxHome. Available at https://www. cdc.gov /dpdx/malaria/2016.

22- Luyendyk J, Olivas OR, Ginger LA, Avery AC. Antigen-presenting cell function during Plasmodium yoelii infection. Infect Immu. 20002; 70: 2941-2949.

23- Suh K, Kain K, Keystone JS. Malaria. CMAJ 2004; 170(11): 1693-1702.

24- Geerligs PDP, Brabin BJ, Eggelte TA. Analysis of the effects of malaria chemoprophylaxis in children on haematological responses, morbidity and mortality. Bull World Health Organ 2003; 81: 205-216.

25- Li Q, Cantilena LR, Leary KJ, Saviolakis GA, Miller RS, Melendez V, et al. Pharmacokinetic Profiles of Artesunate after Single Intravenous Doses of $0.5,1,2,4$, and $8 \mathrm{mg} / \mathrm{kg}$ in Healthy Volunteers: A Phase I Study. Am J Trop Med Hyg 2009; 81(4): 615-621.

26- Dondorp A, Nosten F, Stepniewska K, Day N, White N; South East Asian Quinine Artesunate Malaria Trial (SEAQUAMAT) group. Artesunate versus quinine for treatment of severe falciparum malaria: a randomised trial. Lancet 2005; 366: 717-725. 